\title{
Influence of Tohoku-Pacific ocean earthquake on headache cases in the affected area
}

\author{
Y Matsumori ${ }^{*}$, S Fujiwara ${ }^{2}$ \\ From The European Headache and Migraine Trust International Congress \\ London, UK. 20-23 September 2012
}

\section{Introduction}

On March 11, 2011, Tohoku-Pacific Ocean Earthquake with a magnitude of 9.0 occurred in East Japan, affecting a part of our hospital located in Sendai causing serious damage. The tsunami struck $4 \mathrm{~km}$ away from our hospital. This disaster caused considerable damage to various lifelines including food and medical supplies. Some transportation networks were also paralyzed for several weeks. Although there were such limitations, our hospital continued to conduct medical examination of patients including outpatients.

\section{Purpose}

The aim of this study was to examine how the disaster influenced the headache (HA) medicine at our hospital. Method: We compared the situation of outpatient consultation for HA cases, severity of pain, impact on daily life, and types of $\mathrm{HA}$, which included migraine, tension-type HA (TTH), cluster HA (CH), and medication-overuse HA $(\mathrm{MOH})$.

\section{Results}

The number of outpatient HA cases before the disaster was 9.5 persons/day, and the occurrence rates of the HA types were $62.2 \%$ for migraine, $38.6 \%$ for $\mathrm{TTH}, 3.0 \%$ for $\mathrm{CH}$, and $10.6 \%$ for $\mathrm{MOH}$. The number of HA cases decreased remarkably after the disaster (1.6 persons/day) in March, after which it increased gradually (8.1 persons/ day) in July. After the disaster, although the severity of pain did not change, the impact on daily life because of migraine became significantly worse $(\mathrm{p}<0.001)$. The occurrence rate of migraine increased and that of TTH decreased significantly $(\mathrm{p}<0.001)$. The occurrence rate of $\mathrm{MOH}$ increased slightly, and no change was seen in the occurrence rate of $\mathrm{CH}$.

${ }^{1}$ Department of Headache Medicine, Kohnan Hospital, Japan

Full list of author information is available at the end of the article

\section{Conclusion}

After the disaster, although the HA outpatient consultation rate fell evidently, the occurrence rate of severe migraine increased at our hospital. Although it was difficult to visit a hospital due to difficulties as a result of the disaster, an HA patient particularly with the high impact on daily life visited hospital to seek help.

\section{Author details}

${ }^{1}$ Department of Headache Medicine, Kohnan Hospital, Japan. ${ }^{2}$ Department of Neurosurgery, Kohnan Hospital, Japan.

Published: 21 February 2013

\section{References}

1. Chen CC, Yeh TL, Yang YK, et al:. Psychiatry res 2001, 105:13-22.

2. Chen CH, Tan HK, Liao LR, et al.: Compr Psychiatry 2007, 48:269-75.

3. Guetti C, Angeletti C, Papola R, et al:. J Headache Pain 2011, 12:245-250.

doi:10.1186/1129-2377-14-S1-P22

Cite this article as: Matsumori and Fujiwara: Influence of Tohoku-Pacific ocean earthquake on headache cases in the affected area. The Journal of Headache and Pain 2013 14(Suppl 1):P22.

Submit your manuscript to a SpringerOpen ${ }^{\odot}$ journal and benefit from:

- Convenient online submission

- Rigorous peer review

- Immediate publication on acceptance

- Open access: articles freely available online

- High visibility within the field

- Retaining the copyright to your article

Submit your next manuscript at $>$ springeropen.com
SpringerOpen $^{\odot}$
(C) 2013 Matsumori and Fujiwara; licensee Springer. This is an Open Access article distributed under the terms of the Creative Commons Attribution License (http://creativecommons.org/licenses/by/2.0), which permits unrestricted use, distribution, and reproduction in any medium, provided the original work is properly cited. 